\title{
Identifying Impressive Landscape Objects Based on Geotagged Photographs (A Case Study of Self-Portraits and Ordinary Photos)
}

\author{
Akhmad Arifin Hadi $^{1 *}$, Yusuke Mizuuchi $^{2}$, Tsuyoshi Honjo ${ }^{3}$, Katsunori Furuya ${ }^{3}$ \\ ${ }^{1}$ Departmentof Landscape Architecture, Faculty of Agriculture, Bogor Agricultural University, Indonesia \\ ${ }^{2}$ Graduate School of Agricultural and Life Sciences, The University of Tokyo, Japan \\ ${ }^{3}$ Graduate School of Horticulture, Chiba University, Japan
}

\begin{abstract}
Photographs are important elements in ecotourism activities. The current research utilizes respondents' geotagged photographs to explore the potential landscape objects with its locations. The study invited 61 respondents to come to Bukit Kucing Forest and capture impressive landscape objects. The study used Getis-Org Gi* Hotspot analysis tools in ArcGIS to identify hotspots places based on the numbers of closest photos captured points to five-meters trail segments. There were 1,712 geo-tagged photographs consist of 412 self-portraits and 1,300 ordinary photographs collected from respondents. The finding shows that geotagged photographs, both self-portraits and ordinary photographs, performed hotspots places that containedimpressive landscape objects including: physical structures, wide opening area and panoramic views. Self-portraits' hotspots which were detected more spread and less number than ordinary photographs were able to perform places that werenot detected in ordinary photographs' hotspots. The current work shows that geotagged self-portraits is able to be utilized as object research in identifying hotspots of impressive landscape spaces and objects. The maps of geotagged photographs both ordinary photographs and selfportraits are able to be used as information of visitors' preferences for developing masterplan of ecotourism.
\end{abstract}

Keywords: forest, Geotagged, hotspots, photographs, self-portraits.

\section{INTRODUCTION}

Visitors' preference and behavior are important aspects to be considered in ecotourism management. Information about what potential objects that visitors see and how they react to them is needed to develop sustainable ecotourism programs. In Indonesia, information about preferred objects in a landscape are usually obtained by evaluation or observation studies involving on-site visitors or local people using interview method and questionnaire tools [1,2]. However, these research methods often leave questions regarding authentic evidences that visitor's impressed sightings at the site and where their locations are. Photographs produced by people or participants who do travel activities are possible to be used as supplementary data to illustrate people experience in a travel environment [3].

Photo-based landscape research is one method to identify visitors' visual preference in a forest. Taking photographs is an important

\footnotetext{
${ }^{*}$ Correspondence address:

Akhmad Arifin Hadi

Email : arifin hadi@ipb.ac.id

Address : Department of Landscape Architecture, Bogor Agricultural University, Jl. Meranti Kampus Faperta IPB Dramaga Bogor 16680
}

component in recreation and tourism experiences [4]. Apart from the people who capture them, photos are important indicators of the perception of landscapes in photo-based landscape assessment research [5]. Photographs not only show what people see and how they see it but also how they know and understand the object they see [3]. Research using visitors' photographs can clarify impacts of resources, visitors' perceptions, and experiences, thereby providing valuable input for management and visitor data collection efforts [6].

The self-portraits are a popular photography behavior in tourism and recreational activities. It is a type of photograph in which the main object is the human whose face stares at the camera. Selfie photos are one type of self-portraits but human as main object capture the photos by him or her selves. Selfies show that the person taking the photo was there and witnessed the events in a particular time and space [7]. Taking a selfie is an expression of one's self in a place and time; vacation spots, landmarks, and recreational destinations are common place elements for selfies [8]. Therefore, in this research, we hypothesize that visitor' self-portraits, including selfie photos that complemented by geotagged information reflect popular places and identify impressive landscape as self-portrait background. 
GPS technology and research using GPS tools to track visitors has been conducted since around 2005 [9]. Since then, the use of GPS tracking has contributeto photo-based landscape research. Through GPS tracking, it is possible for researchers to trackthe location of visitors' captured photos, assign geotagging information to photos and use GIS technology to detect trends and hotspots of locations captured in photographs $[10,11]$.

The objective of the current research is to identify impressive landscape views based on visitors' geotagged photos captured while walking in Bukit Kucing Forest. The study aimed to investigate if photo-based research can be implemented for Indonesian ecotourism site, based on the fact that taking photos is popular behavior among Indonesian tourist. Using geotagged photographs, the information obtained is about both the content of the photographs and the location where they were captured which is an important input for forest management. We detected photographs hotspots as impressive viewing places and identified the popular landscape as elements captured by respondents.

\section{RESEARCH METHOD}

\section{Study Site: Bukit Kucing Forest}

Bukit Kucing Forest is a protected area in the middle of Tanjungpinang City, capital of Riau Island Province, Indonesia. The province comprises 2,408 islands, and Bukit Kucing Forest is located on Bintan Island (Fig. 1), $462 \mathrm{~m}$ south of the coastal line. The site is influenced by the coast in terms of biodiversity. The total area of the forest is 54.4 ha which is surrounded by settlements. The area has been well preserved since the Johor-Riau-Lingga Kingdom era. The forest is open for visitors' recreation and local people's activities, such as bathing, collecting water, and washing clothes. The types of recreation activities include sightseeing, trekking, and camping. Forest guards employed by the city government protect the site from illegal logging, forest fires, hunting, and other illegal activities [12].
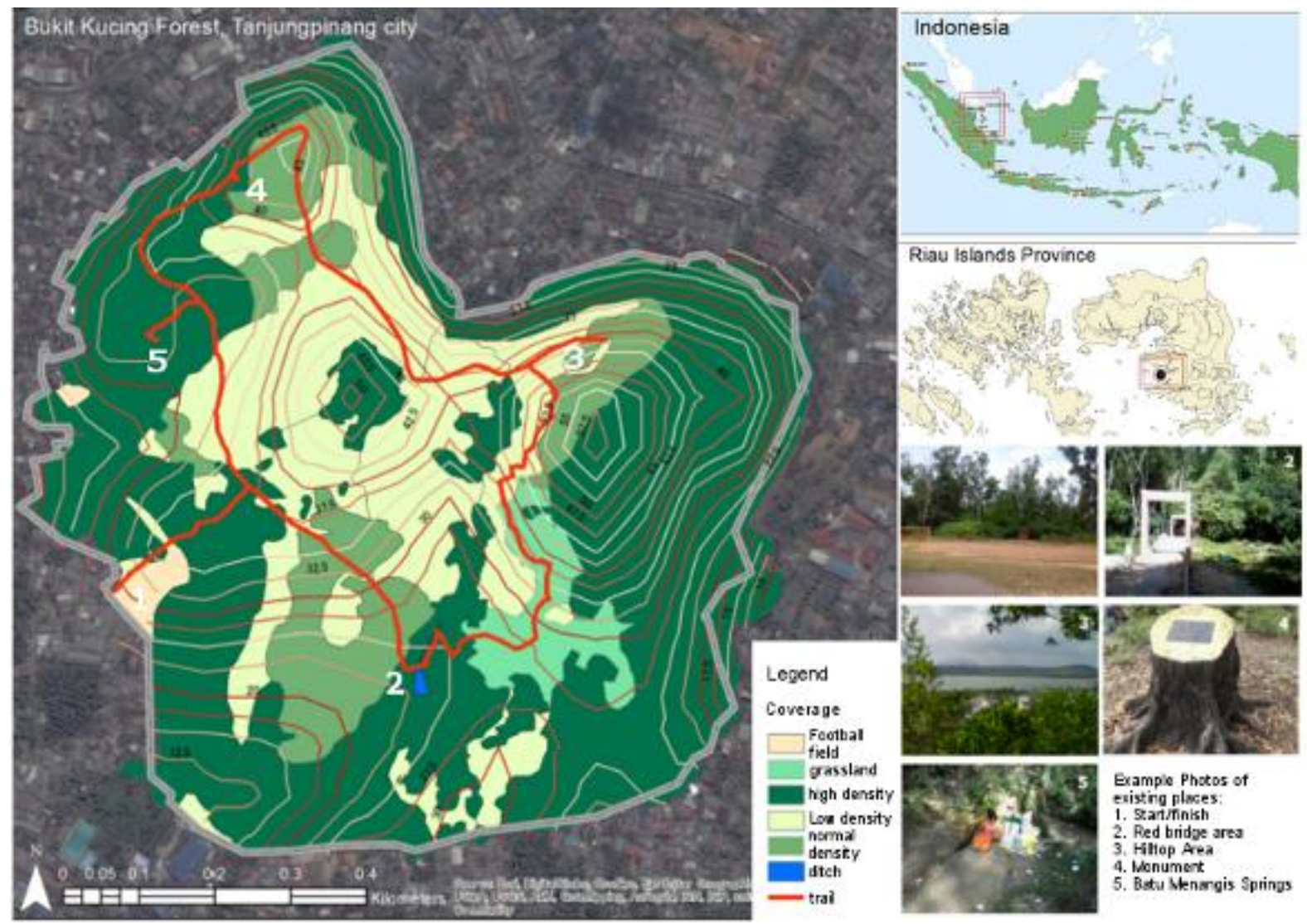

Figure 1. Location of Study 
As the main green open space in Tanjungpinang City, Bukit Kucing Forest serves numerous functions including water catchment and wildlife conservation. It provides a habitat for various birds, including the predatory eagles that fulfill an important role in the ecosystem. A large variety of unique vegetation rarely found in other places on Bintan Island also grows in the forest [13].

\section{Predefined Trail}

The predefined trail passes a number of recreation locations including: the Red Bridge area, hilltop gazebo with a city view, historic inscriptions sculpture and Batu Menangis Rock Springs (Fig. 1). The trail runs a length of 2,695 m counter clock wise in a loop, with a similar start and finish point at the Forest Guards' base camp. With the weather and various slopes, visitors need at least 1 hour and 30 minutes (i.e. without taking pictures) to complete a loop on this trail.

\section{Tools}

The current study asked respondents to use their own smartphones or camera phones to take photographs. Thus, the study took advantage of the ubiquity of the use of such devices among Indonesians. Geo-tagging is a technology integrated in modern smartphone and camera devices. However, to ensure the accurate location of the photographs captured by each respondent, each was given a GPS logger (I-gotU GT 120 GPS Logger from Mobile Action Technology, Inc, with an SiRF Star III Low Power chipset), which can auto-map the GPS location of photos captured with accuracy 10-20 m. Before distributing the GPS loggers, the time setting on the respondents' cell phone, smartphone, or camera was synchronized with the western Indonesian time zone.

\section{Participants}

The respondents were 61 university students in Tanjungpinang City: 56 students from University of Maritime of Raja Haji Ali (Umrah University), 10 from Sekolah Tinggi Ilmu Sosial dan Ilmu Politik (STISIPOL) Raja Haji Tanjungpinang, and 2 from Sekolah Tinggi IImu Ekonomi Pembangunan (STIEP) Tanjungpinang. Respondents were selected based on assumption that the university students possessed the appropriate knowledge to offer objectives evaluations of Bukit Kucing Forest. Regarding their educational background, none majored in landscape or forestry. As such, the respondents represent regular visitors to the forest.
Students who were interested joining as participants were invited to a short orientation meeting on March 23, 2015. The invitations were distributed with the help of Umrah University administration officials and the Mahapala nature conservation students' organization using the short message service (SMS). The on-site survey was conducted from March 24 to 27, 2015, and the number of students per day was limited to 20 because of the limited number of GPS logger units.

\section{Procedure}

Respondents were asked to demonstrate the landscape that impressed them in Bukit Kucing Forest by taking photographs. Respondents came to the start/finish point in the Forest Guard base camp. Before they traversed the specified trail, the researcher explained the route, procedure for capturing photographs, and the use of the GPS logger. Afterwards, the forest guard explained rules to observe while walking at the forest. Subsequently, each respondent was lent a GPS logger, which was placed in the respondents' bag, hand, or trouser pocket. Respondents were asked not to push the button of the GPS logger during the walk. The GPS loggers recorded their positions on the trail when taking photographs according to the time setting. As the forest did not have a direction map, respondents were divided into three groups, each guided by a forest guard. Although this procedure had the risk of respondents being influenced by other people [14], this option was deemed the best choice for safety reasons.

On site, respondents were asked to take photographs that the landscape impressed them, using their cellphone, smartphone, or camera device. As the Internet connection in Tanjungpinang City was weak, it was difficult to ask respondents to send their digital pictures to the researcher online. Therefore, all pictures captured by respondents were transferred to the researcher's laptop after they had completed walking the trail.

At the finish point, students were asked to return the GPS logger, and the researcher copied the GPS logger file to a laptop. Each respondent was given a transportation fee after the image and GPS logger files were transferred to the researcher's laptop.

\section{Analysis Method}

The time stamps of respondents' photographs were matched with data from the GPS loggers' using @trip software. The data used 
for the next step was collected from the geotagged photographs exported into ArcGIS software to obtain photographs points on a map. The next step entailed the analysis of geo-tagged pictures in ArcGIS. Basic data was obtained from the City Government of Tanjungpinang on the: site boundary, contour line with interval contour of $0.50 \mathrm{~m}$, islands of the province, and city roads in a geo-database file and actual site plan in a .jpg file.

The data on photographs points in ArcGIS was analyzed to obtain distribution and hotspot trends. A hotspot is marked by a concentration of photographs points corresponding to the quantity of photograph staken by the respondents. The data were analyzed using Hotspot analysis Getis-Ord Gi* tools, which calculates the statistics of each feature in a dataset where the resultant Z-score indicates whether the features have high or low values clustered spatially. Here, each feature was examined within the context of neighboring features. In the analysis, the trail was divided into five-meter segments. All geo-tagged points close to each of the segments were counted to obtain the standard deviation ( $\mathrm{z}$ values). A segment becomes a hotspot if the geo-tagged points have a z-score higher than 1.96, indicating 95\% confidence. The hotspots of ordinary photos and self portraits were compared to obtain differences in respondents' preferred landscape elements.

\section{RESULT AND DISCUSSION Respondents' Identity}

The average age of respondents was 20 years, and the age range was 18 to 31 years. Regarding gender, $48.21 \%$ of the respondents were male and $51.79 \%$ female. More male respondents reported having previous knowledge and awareness of the site before the site survey. However, only nine male and two female respondents had visited the site before the site survey. Respondents mostly came from other cities (67.86\%), and were living in rented rooms in Tanjungpinang since starting their university studies. In total, of $64.29 \%$ respondents who came from cities other than Tanjungpinang had never visited the site.

\section{Respondents' Geo-tagged photos}

From 61 respondents, 1,712 geo-tagged photographs were collected. The geo-tagged photographs were analyzed according to two categories, namely self-portraits and nonselfportraits photos. Next, the non-self portrait photos will be called as ordinary photos. A photograph was categorized as self-portraits if it featured a human whose face staring at the camera. The self-portraits could be photos captured by respondents' holding camera (selfie photos) or taken by other people (assisted selfportrait). On the other hand, the ordinary photos are photos without human as main object.

Not all respondents captured self-portrait at the site. As such, 9 respondents (14.76\%) did not take self-portraits at the site. thus, 412 selfportraits were produced by the 52 respondents (85.24\%) who captured self-portraits during their walk. The vantage points of each respondent's photographs were detected by the ArcGIS software. The Getis-Ord Gi* hotspot analysis tool was used to analyze the concentration of capture points that close distance with five-meters segments along the predefined trail that next will be called as hotspots segments. Figures 2 shows the hotspots of trail segments indicated by thicker red lines are more significant than other segments. The self-portraits capture points were represented by $x$ symbols along trail and the ordinary photos capture points are represented by + symbols.

\section{Ordinary Photographs Hotspots}

There were 1,300 Ordinary photos captured by respondents. There were 4 hotspots places performed by 411 Ordinary photographs (Table 1). Hotspots $A$ is the most popular hotspots place with 203 ordinary photographs. In this area, there are various types of landscape elements that impressed respondents and captured them as photographs' objects. Mostly photographs of hotspots A consist of physical structures $(34.98 \%)$, trees and shrubs $(21.67 \%)$, corridor $(19.21 \%)$, part of plants $(11.82 \%)$, natural features $(10.34 \%)$ and the rest is animals and opening area (1.98\%). Based on the photos content, the bridge is the most physical structures captured in photographs of these hotspots. The hanging style and red color of the structure makes the bridge easy to spot from a distance and breaks the monotonous green color of the surrounding trees and shrubs. Here, contrast as a landscape design principle, is prominent in the design of the bridge and influences its composition, all of which attract visitors' attention. The design of the Red Bridge is also unique compared to the other bridges in Tanjungpinang City. The bridge is not only captured as a target object of photographs, it is 
also a vantage point that enabled respondents to capture surrounding objects.

Hotspots B consist of 146 ordinary photographs. The photographs mostly contained with opening area of grassland (43.84\%) followed by part of plants $(24.66 \%)$, trees and shrubs (16.44\%), animals and animals' imprints (9.59\%) and rest of them are natural features and panoramic view $(5.47 \%)$. The grassland forms a wide bit of scenery that makes it possible for respondents to see trees in the far distance as background. Unlike in other parts along the predefined trail, the trees in the area offer less canopy coverage and provide full sun that reaches the forest floor. Therefore, it offered a wide landscape scene and attracted respondents to stop and document the view. The part of plants and animals that fewer captured in other hotspots were captured more in this place. Those objects are potential objects that need to be more explored as attraction in ecotourism programs of Bukit Kucing Forest.

Table 1. Number of Focused Objects Captured in each Ordinary Photos' hotspots

\begin{tabular}{lccccc}
\hline \multirow{2}{*}{ Background } & \multicolumn{5}{c}{ Hotspot } \\
\cline { 2 - 5 } & A & B & C & D & \\
\hline Trees \& Shrubs & 44 & 24 & 2 & 3 & 73 \\
Opening Area & 2 & 64 & 0 & 0 & 66 \\
Part of Plant & 24 & 36 & 2 & 2 & 64 \\
Animal & 2 & 14 & 0 & 0 & 16 \\
Corridor & 39 & 0 & 1 & 0 & 40 \\
Natural Features & 21 & 4 & 0 & 0 & 25 \\
Structures & 71 & 0 & 2 & 18 & 91 \\
Panoramic view & 0 & 4 & 31 & 1 & 36 \\
\hline total photos influence & 203 & 146 & 38 & 24 & 411 \\
hotspots & & & & & \\
\hline
\end{tabular}

Hotspots C consist of 38 ordinary photographs. Similar with the trend of self-portraits background, the focused objects of photographs of hotspots $C$ is mostly consist of panoramic view of Tanjungpinang city. The panorama of the city in lower elevation can be seen from this hilltop. A $9.50 \mathrm{~m}^{2}$ gazebo is located on the hilltop, which become resting points for respondents walking up the ascending slope. While resting, respondents enjoyed a panoramic view of Tanjungpinang City and took photographs.

Hotspots D consist of 24 photographs which is the fewest number of photographs hotspots of ordinary photos. The photographs in these hotspots mostly consist of the Historic Inscription Sculpture as focused objects (75\%). The sculpture looks regular, but on the logged part, there is a historic inscription noting replanting activities in 1989 as supervised by City Major of Tanjung- pinang. Respondents were interested in the history of Bukit Kucing Forest; therefore, they captured it in photographs.

\section{Self-Portraits Hotspots}

Total 412 self-portraits captured by respondents, 108 photos influenced appearance of 7 hotspots of trail segments (Fig. 2). This means that in those segments, the number of closest self-portraits points is more than other segments that are not hotspots. The number of self-portraits in each hotspot segment differs (Table 2). In hotspots 1 , nine photographs were taken with the Melaleuca cajuputi trees understory as background. In hotspot 2 which is similar location with hotspots $A$ in ordinary photographs', 42 photographs were taken at the Red bridge area. For hotspot 3 which is similar location with hotspots B in ordinary photographs, seven photographs included the grassland area and hotspots 4 which is similar location with hotspots $C$ in ordinary photographs included 19 photographs of the hilltop area. Hotspot 5 included 8 photographs of corridor with shrubs on left and right sides of corridor. In hotspot 6 which is similar location with hotspot $D$ in ordinary photographs, 16 photographs included the Historical Inscriptions Sculpture. In hotspot 7, seven photographs captured the Acacia trees understory as background.

Table 2. Number of Background Scenes Captured in each self-portraits hotspot

\begin{tabular}{lccccccccc}
\hline \multirow{2}{*}{\multicolumn{1}{c}{ Background }} & \multicolumn{1}{c}{ Hotspot } & Total \\
\cline { 2 - 9 } & $\mathbf{1}$ & $\mathbf{2}$ & $\mathbf{3}$ & $\mathbf{4}$ & $\mathbf{5}$ & $\mathbf{6}$ & $\mathbf{7}$ & \\
\hline Trees \& Shrubs & 6 & 2 & 1 & 6 & 6 & 4 & 6 & 31 \\
Opening Area & 1 & 0 & 6 & 0 & 1 & 0 & 0 & 8 \\
Part of Plant & 0 & 0 & 0 & 1 & 0 & 0 & 1 & 2 \\
Animal & 0 & 0 & 0 & 0 & 0 & 0 & 0 & 0 \\
Corridor & 1 & 5 & 0 & 1 & 1 & 2 & 0 & 10 \\
Natural Features & 0 & 2 & 0 & 0 & 0 & 0 & 0 & 2 \\
Structures & 1 & 33 & 0 & 4 & 0 & 10 & 0 & 48 \\
Panoramic view & 0 & 4 & 31 & 1 & & & & 7 \\
\hline total photos & 9 & 42 & 7 & 19 & 8 & 16 & 7 & 411 \\
influence hotspots & & & & & & & & \\
\hline
\end{tabular}

There are hotspots 1, 5 and 7 of self portraits that were not hotspots for ordinary photographs. Although the number of self-portraits and ordinary photographs were different, but it shows that the self-portraits were able to show more numbers of popular places than ordinary photographs. Self-portraits with understory spaces as background were mostly taken in hotspots 1 and 7 . The self-portraits in hotspots 1 were mostly taken under $M$. cajuputi tree canopy in between of spongy bark trunks with less of shrubs on the forest's floor (Fig. 3). This is 
distinguishing characteristic of the $M$. cajuputi, which is mass planted among other trees. The unique feature in hotspots 7 is the understory of Acacia auriculiformis trees. Similar to hotspot 1, this area is characterized by fewer shrubs in the understory below Acacia tree canopy. The floor of the forest is clearly visible covered by the fallen leaves and trunk's texture of Acacia trees. Shrubs as self-portraits background were evident mostly in hotspot 5 . There are many dense shrubs on left and right sides of the corridor. Actually, there is no specialty in the morphology of the shrubs, but because it form vertical sparse wall, some respondents stopped for a while and took photographs with the shrubs as background.

However, there were objects that less captured in self-portraits background but more captured in ordinary photos. These objects are small detailed landscape objects such as part of plants, animals, animals' imprints and natural features. It shows weakness of self-portraits that respondents difficult to capture small detailed elements as self-portraits background.
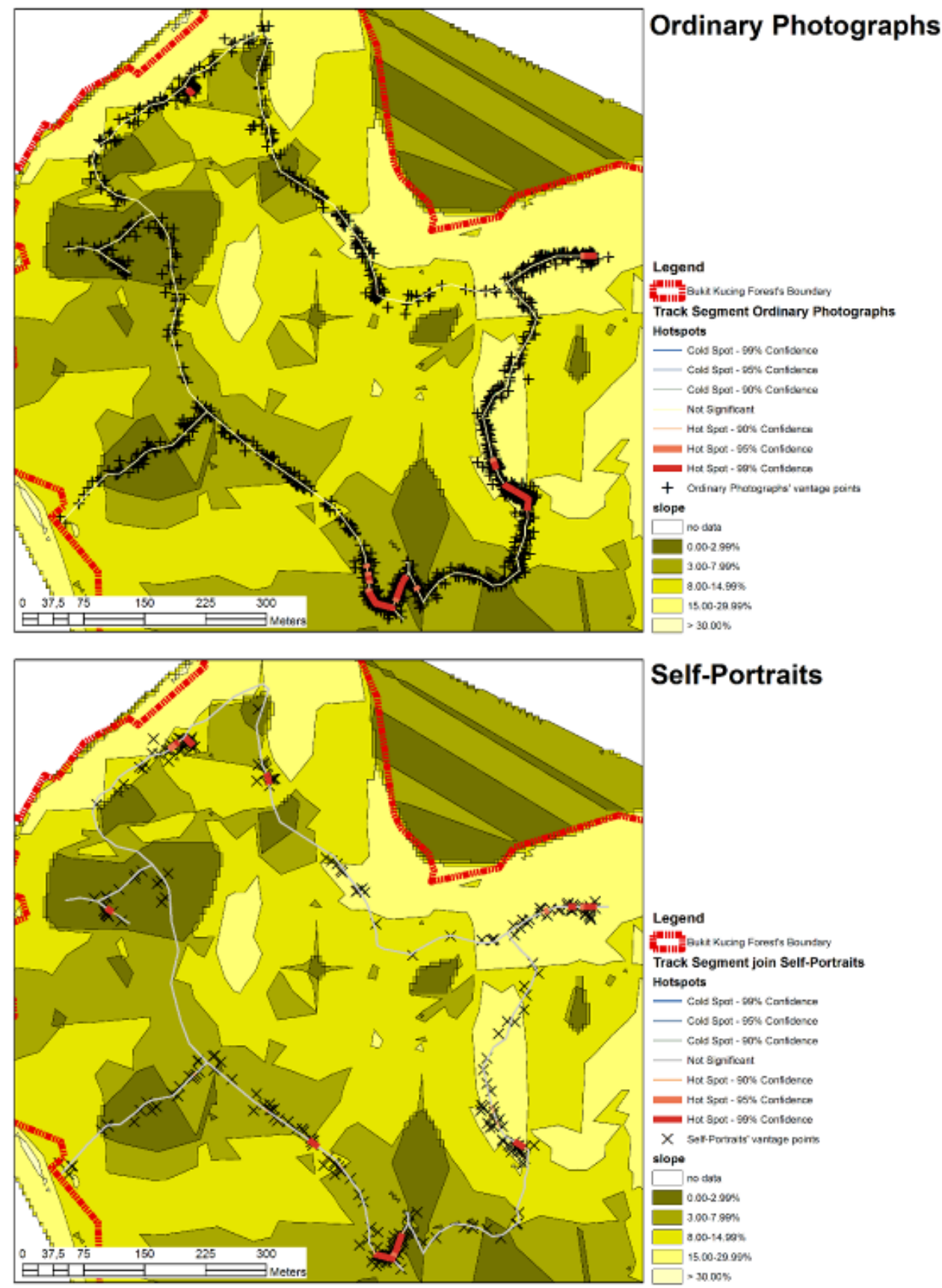

Figure 2. Hotspots Map of Ordinary Photographs and Self-Portraits 


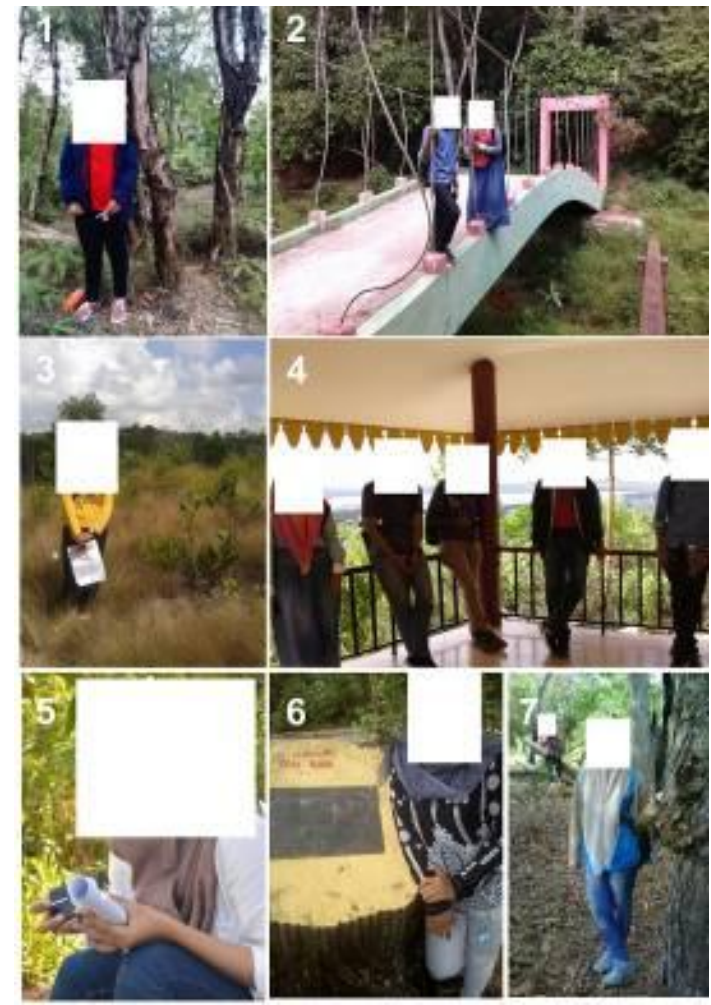

Figure 3. The examples of self-portaits with background scenes

Description: 1) Hotspots 1 ; 2) Hotspots 2; 3) Hotspots 3; 4. Hotspots 4; 5) Hotspots 5; 6) Hotspots 6; 7) Hotspots 7

\section{General Discussion}

The geotagged photographs is useful to perform locations and hotspots of where photographs taken as shown in Figure 2 . According to the procedure of taking photographs in this research, the geotagged photographs captured by respondents reflect the popular locations and landscape objects that impressed respondents. It is similar result with other geotagged photo-based research $[10,11,13]$ that the geotagged photographs able to perform places and preferred objects on a particular sites.

The ordinary photographs were more concentrated into fewer hotspots places than self-portraits. It identified from number of hotspots places of ordinary photographs which is located on 4 hotspots influenced by 411 ordinary photographs while self-portraits hotspots are located on 7 hotspots influenced by 108 selfportraits. The ordinary photos hotspots more concentrated to 4 places with more number of photos than self-portraits hotspots. This means that the impressive landscape objects as focused objects of photographs were mostly exist in those 4 hotspots.

The structures object is the most impressive objects captured in ordinary photos $(22.14 \%)$ and self-portraits (44.44\%) of all hotspots. It is similar result with [11] that "structures" is a type of landscape elements that attracts visitors' attention in a park. The Red Bridge is the most structure taken in respondents' photographs. The Red Bridge is not only captured as an object but also hotspots of vantage points. It is similar result with [13] that bridge is not only an impressive object but also become a sightseeing resource to see space surrounded.

The novelty of this research is the use of geotagged self-portraits to perform impressive landscape spaces or objects. The self-portraits including selfie is a new way in touristic looking in tourism activities [14]. The selfie studies usually consist of people behavior towards time and spaces. But selfie photos combined with GPS tracking was not used. However, the use of selfportraits in photo-based landscape research to identify people's preference is rarely implemented. In this research, the geotagged self-portraits is able to perform impressive landscape spaces by vantage points and hotspots detection although this type of photographs is influenced by subjective tendency of respondents to show him/herself in photos.

\section{CONCLUSION}

The result showed that geotagged photographs offer opportunities as objects of research. Especially, the landscape elements and features captured in self-potrait background scene is possible to be the most impressed landscape view that the capturer has tendency to record the moment in photos and include themselves into the picture.

The photographs, both self-portraits and ordinary portraits should be complemented by information of where the photos captured by geotagged information. The photographs that complemented by geotagged information, performed respondents' tendency of places, moments and which landscape view is impressive for them. This information is important to analyze respondents' or visitors' impressed landscape in an ecotourism program.

The current work that has succeeded to identify the concentration of vantage points is useful information for landscape managers in planning attractions in Bukit Kucing Forest. According to its benefits, a geotagged photo- 
based study with GIS technology is recommended to be implemented in recreational or ecotourism forests. For a growing ecotourism site such as Bukit Kucing Forest, geotagged photo-based study results help planners optimize existing attractions and create new places of interest. The hotspots of selfies should be considered by management of Bukit Kucing Forest to prevent the view from destructions.

\section{REFERENCES}

[1] Hakim, L. and C. Retnaningdyah. 2014. Ecological and social evaluation of coastal tourism destination development: a case study of Balekambang, East Java. Journal of Indonesian Tourism and Development Studies 2(1), 26-32.

[2] Kurnianto, A. S., F. Alifianto, H.D. Prasetyo and B. Rahardi. 2013. Eksplorasi beberapa jalur potensi wisata Birdwatching di Bandealit, Taman Nasional Meru Betiri. Journal of Indonesian Tourism and Development Studies 1(1),12-19.

[3] Albers, P. C. and W. R. James. 1988. Travel photography - a methodological approach. Annals of Tourism Research 15(1), 134-58

[4] Markwell, K. W. 1997. Dimensions of photography in a nature-based tour. Annals of Tourism Research 24(1), 131-155.

[5] Jacobsen, J. K. 2007. Use of landscape perception methods in tourism studies: a review of photo-based research approaches. Tourism Geographies 9(3), 234-253.

[6] Dorwart, C. E., R. L. Moore and Y. F. Leung. 2007. Visitor employed photography: its potential and use in evaluating visitors' perceptions of resource impacts in trail and park settings. Proceeding of 2006 Northeast Recreation Research Symposium, 9-11.

[7] Koliska, M. and J. Roberts. 2015. Selfies: witnessing and participatory journalism with a point of view. International Journal of Communication 9, 1672-1685.

[8] Hess, A. 2015. The selfie assemblage. International Journal of Communication 9, 1-18.

[9] Shoval, N. and R. Ahas. 2016. The use of tracking technologies in tourism research : a review of the first decade. Tourism Geographies 6688 (November), 1-20.

[10] Mizuuchi, Y., Y. Son, M. Kang and K. Furuya. 2015.Constructing a survey method for landscape evaluation using visitor employed photography and GPS. Landscape Research Japan Online 8(1), 1-7.

[11] Sugimoto, K. 2011. Analysis of scenic perception and its spatial tendency: using digital cameras, GPS loggers, and GIS. Procedia - Social and Behavioral Sciences 21, 43-52.

[12] Bukit Kucing Protected Forest. 2016. Satuan Pengamanan Hutan (SATPAMHUT). Available at: https://loveshapedforest. wordpress.com/satuan-pengamanan-hutansatpamhut.

[13] Research Center for Biomaterials. 2013. Rehabilitasi Hutan Lindung Bukit Kucing. Indonesian Institute of Sciences. Available at: http://www.biomaterial.lipi.go.id/reha bilitasi-hutan-lindung-bukit-kucing/.

[14] MacKay, K. J. and C. M. Couldwell. 2004. Using visitor-employed photography to investigate destination image. Journal of Travel Research 42(4), 390-396. 